Terr. Atmos. Ocean. Sci., Vol. 17, No. 4, 645-658, December 2006

\title{
The Geological Structure and Prospect of Gas Hydrate over the Dongsha Slope, South China Sea
}

\author{
Pin Yan $^{1,}$ 2, * , Hui Deng ${ }^{1}$, and Hailing Liu ${ }^{1}$
}

(Manuscript received 21 October 2005, in final form 12 August 2006)

\begin{abstract}
The area around the Dongsha Island in the northeastern South China Sea was generally known for the occurrence of gas hydrate related features, like BSR, cold seep carbonates and chemoautotrophic bacteria. To precisely evaluate the potential of gas hydrate occurrence in the NE South China Sea, marine geology of the large Dongsha slope region is studied based on more geophysical and geological data including multiple-channel seismic and high resolution sub-bottom topographic images. The east Dongsha slope area represents the largest slumping zone in the northern slope of the South China Sea, and might exhibit the highest potential of gas hydrate occurrences. The central Dongsha slope area, with very thin Cenozoic sediments, was tectonically disturbed by the latest Cenozoic uplifting and magmatism events, therefore is unfavorable for gas hydrate occurrence. The west Dongsha slope area with the deepest Cenozoic depression and moderate to minor slumping bodies might be favorable for gas hydrate occurrence.
\end{abstract}

(Key words: Dongsha slope, Submarine slump, Gas hydrate)

\section{INTRODUCTION}

Fast global economic development requires more energy supply worldwide. Gas hydrate could be one of the most significant energy sources in the near future. More and more gas hydrate occurrences have been found in the worldwide oceans and marginal seas in addition to polar continental areas. These factors become a major impetus to stimulate the exploration and development study of gas hydrate offshore China. In the past few years, geophysical and geo-

\footnotetext{
${ }^{1}$ Key Laboratory of Marginal Sea Geology, Chinese Academy of Sciences, Guangzhou, China

${ }^{2}$ Guangzhou Center for Gas Hydrate Research, Chinese Academy of Science, Guangzhou, China

* Corresponding author address: Dr. Pin Yan, Key Laboratory of Marginal Sea Geology, Chinese Academy of Sciences, Guangzhou, China; E-mail: yanpin@scsio.ac.cn
} 
logical reconnaissance cruises have been conducted over the northern continental slope of the South China Sea. As a result, geophysical, geochemical and/or geological indicators, such as BSR, seep carbonates, etc., have been found or deduced to support the presence of gas hydrates at several portions/localities along the slope (Chen et al. 2004, 2005; Chi et al. 1998; Deng et al. 2005; McDonnell et al. 2000; Schnürle et al. 1999; Shyu et al. 1998; Song et al. 2001; Wu et al. 2003a; Wu et al. 2005; Yao 1998), among which the Dongsha Slope and the SW Taiwan Waters are believed to be most prospectful in gas hydrate accumulation.

Located in the southeast quadrant of the northern margin of the South China Sea (Fig. 1), the circum-Dongsha Islands slope region is quite complex in geology due to its Cenozoic tectonic history of early continental rifting and drifting, and late post-drifting magmatism and uplifting. The complex geology is manifested by rough areal variations of fault activity, sedimentary patterns and magmatism. The aim of this paper is to analyze the likelihood of gas hydrate accumulation over the region under the complex tectonic process and sedimentary environment with previously and recently collected geophysical and geological data.

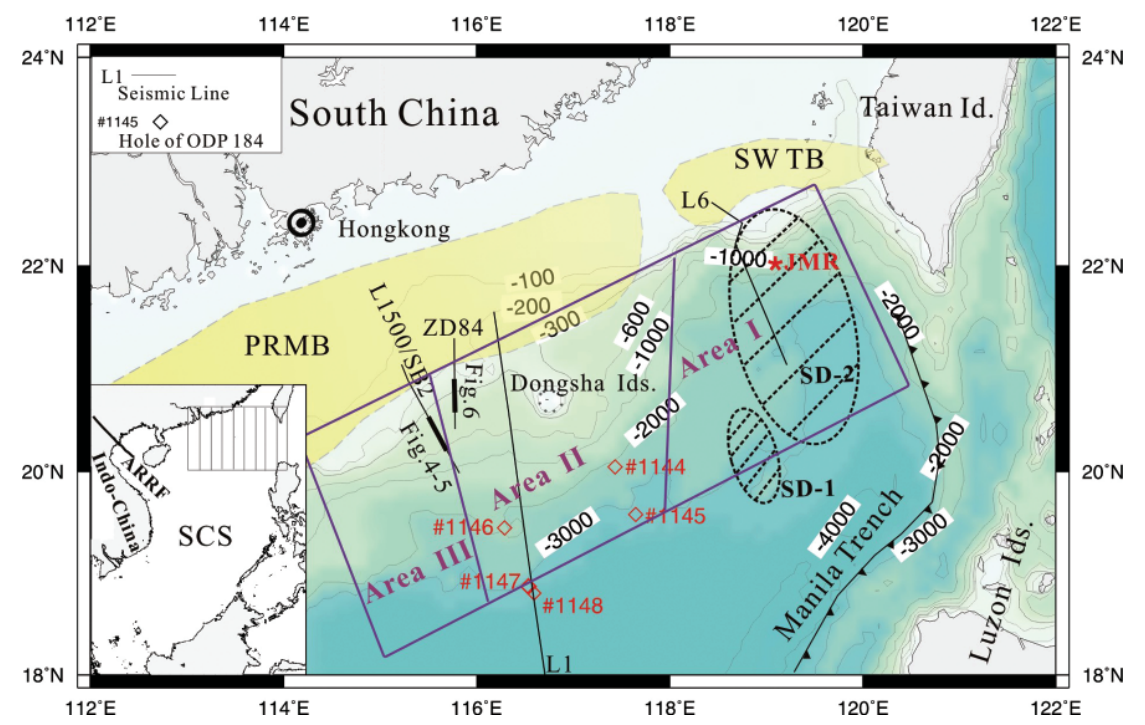

Fig. 1. Bathymetry chart over the northeastern part of the South China Sea and location of geological survey lines, sedimentary dredges and ODP sites. The bathymetry contour is in meters. JMR = Jiulong Methane Reef. SWTB $=$ Southwest Taiwan Basin; PRMB = Pearl River Mouth Basin. ARRF: Ailaoshan-Red River Fault. SCS = South China Sea. SD-1, SD-2 denotes two large slide/slump complexes. Multiple channel seismic profiles: L1, L1500, L6; Single channel seismic profile: ZD84; Sub-bottom seismic profile: SB2. 


\section{GEOLOGICAL SETTING}

Continental rifting since the Late Cretaceous and subsequent drifting during the late-Oligocene to the mid-Miocene (Taylor and Hayes 1983) has produced a series of sedimentary basins on the resulting margins. The northern margin of the South China Sea trends in a roughly NE direction. It is dissected by the Taiwan-Luzon Arc in the east and is sheared out by IndoChina block in the west along Ailaoshan-Red River Fault and its seaward continuation (Fig. 1). Basically, it is a non-volcanic passive margin despite weak magmatism during its rifting and spreading phase, and young volcanism activation during the closing of the oceanic basin (Yan et al. 2001, 2006). Since the cessation of the sea floor spreading, the margin has sustained a tectonic subsidence tendency. Wealthy sediments have been transported from South China and Taiwan southward into the shelf and slope basins. The maximum thickness of Cenozoic deposits exceeds $10 \mathrm{~km}$ in the slope basins where rich petroleum resources have been developed or are being explored (Pang et al. 2004).

The Dongsha Islands are perched on a relatively stable Mesozoic block that has survived the Cenozoic continental stretch and rift. The Mesozoic block, covered with thin Neogene deposits, is also named the Dongsha Rise (Fig. 1). Considerably thick ( $>5 \mathrm{~km}$ ) Mesozoic strata were interpreted to exist to the southeast of the islands (Hao et al. 2001). However, short-lived uplifting events after mid-Miocene (Lüdmann and Wong 1999) were found accompanying bursts of magma eruptions around the Dongsha Islands and along the continental-oceanic transitional zone (Yan et al. 2001, 2006). Lüdmann and Wong (1999) conjectured that the cause of the uplifting and magmatism events is of the collision of the South China margin with the Taiwan-Luzon Arc. The term Dongsha Slope here denotes a large continental slope encompassing the Dongsha Islands from the eastern Pearl River Mouth Basin to the junction of the South China slope with the southwest Taiwan slope (Fig. 1). Presence of the Dongsha Rise (roughly Dongsha Islands northward upper slope) makes the bathymetric contours bulge southward. The southwest Taiwan slope strikes in a NNW-direction. For the sake of convenience to describe the local geology, we subdivided the different sectors of Dongsha Region into an eastern area (I), central area (II) and western area (III) (Fig. 1).

\section{PREVIOUS STUDY}

In the past two decades, the China National Offshore Oil Corporation, the Guangzhou Marine Geological Survey (GMGS) and South China Sea Institute of Oceanology (SCSIO) have, independently or jointly, conducted extensive geophysical surveys for petroleum exploration and development, submarine hazard evaluation and academic study. The survey lines concentrated within the shallow slope (water depth $<500 \mathrm{~m}$ ) north of the Dongsha Islands. Sparse reconnaissance lines with or without dredging have been run previously (Damuth 1980; Lüdmann and Wong 1999) and recently across the region, through the lower slope to the central oceanic basin of South China Sea. In 1999, Leg 184 of ODP has drilled four sites in south Dongsha Island, historically into the lower slope (Fig. 1). In 2002, the GMGS dredged sedimentary samples over a northeastern corner to the Dongsha Islands. Stimulated by the finding of seep carbonates et al. (Chen et al. 2005), a favorable proxy for gas hydrate, the 
GMGS has repeated dredging there via the charting of the Germany RV Sonne (Fig. 1) in 2004.

From these recent surveys, three important discoveries presumably related to gas hydrate were claimed over the Dongsha region: (1) Discovery of BSR (bottom simulating reflector) on several seismic lines over the lower slope south to the Dongsha Islands, among which, the Sites 1144 and 1148 of ODP 184 Leg were located (Song et al. 2001); (2) Discovery of large cold vent carbonates accompanying a strong methane anomaly in the upper slope of the eastern Dongsha Islands area (Huang et al. 2005a); (3) Discovery of methane oxidizing archaea and sulfate reducing bacteria fossils which suggest gas venting on the seafloor of the northeast corner to Dongsha Islands (Chen et al. 2005).

\section{GEOPHYSICAL AND GEOLOGICAL SURVEY}

Within the past few years, the SCSIO has collected multiple channel seismic data and sub-bottom seismic data over the Dongsha region (Fig. 1). The seismic data were collected using a DFS-V seismometer with an $1200 \mathrm{~m}$ streamer, and an EdgeTech 3200XS sub-bottom profiler (specific frequency range $500 \sim 12000 \mathrm{~Hz}$ ) onboard $R / V$ Shiyan II. Additionally, the SCSIO has joined a Chinese National Basic Research Priorities Programme, which collected seismic data using a MSX streamer and recording system onboard the GMGS' $R / V$ Tanbao in 2002. The MSX streamer was $3000 \mathrm{~m}$ long with 240 channels.

\section{RESULTS}

\subsection{Northeastern of Dongsha Area (Area I)}

In the junction area of the northeast slope of the South China Sea and the SW slope of Taiwan Island, there is a northward protruding corner of bathymetric contours (Fig. 1). There, a seismic line run onboard $R / V$ Tanbao from the shelf southward to the lower slope reveals a huge submarine landslide-slump zone (Figs. 2,3). The wide shelf and the shallow sediments are very flat. The shelf break lies at $150 \mathrm{~m}$ depth where the slope emerges sharply. Water depth increased from $\sim 150 \mathrm{~m}$ at the shelf break to $3000 \mathrm{~m}$ within a span of only $60 \mathrm{~km}$. The uppermiddle slope is very narrow. Sliding faults appear from the shelf break in sub-vertical angle, becoming low angle sliding surface to the lower slope. Numerous submarine valleys and peaks lead the submarine topography very rugged. Seismic facies within $1 \mathrm{~s} \mathrm{(two} \mathrm{way} \mathrm{time)} \mathrm{beneath}$ the seafloor appear chaotic and weak over the upper and middle slope. Slump-derived deformations are very common in the shallow sediments, whereas deeper reflections are more continuous and stronger which implies negligible or possibly null effect of tectonic activity. With the Cenozoic stratigraphic scheme presented by Yan et al. (2001), interpretation to partial seismic reflectors are given in Fig. 2b. An evident basement high can be identified as an abutting body against the landslide. Well correlated with a regional high magnetic zone trending in NE direction (Sibuet et al. 2002; Cheng 2004), the basement high is interpreted as a synrifting basaltic unit. 

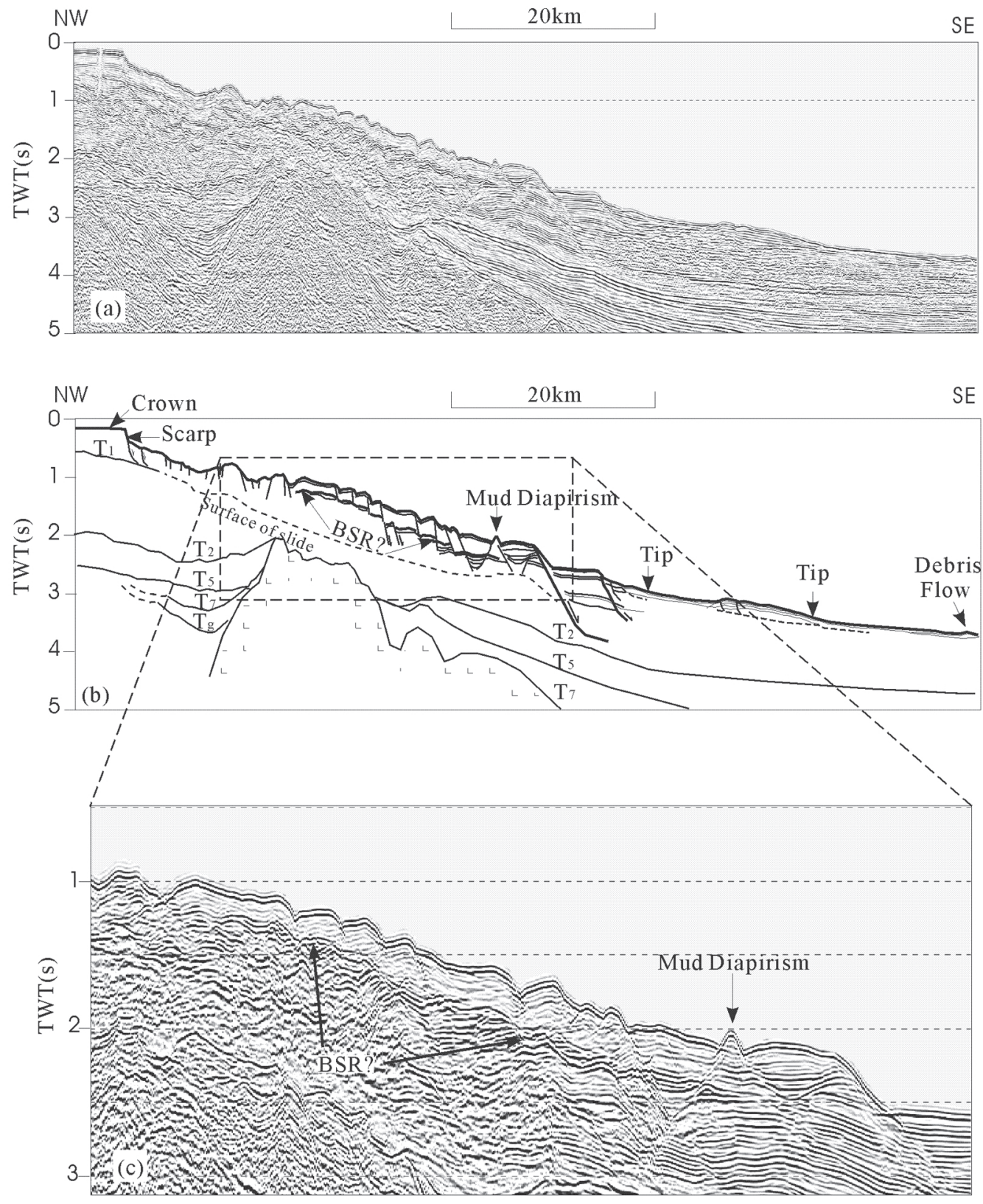

Fig. 2. Migrated (a) and interpreted (b) seismic profile L6 shows a huge landslide-slump body in the northeast corner of the South China Sea. Possible BSRs appear at mid-slope (b). 


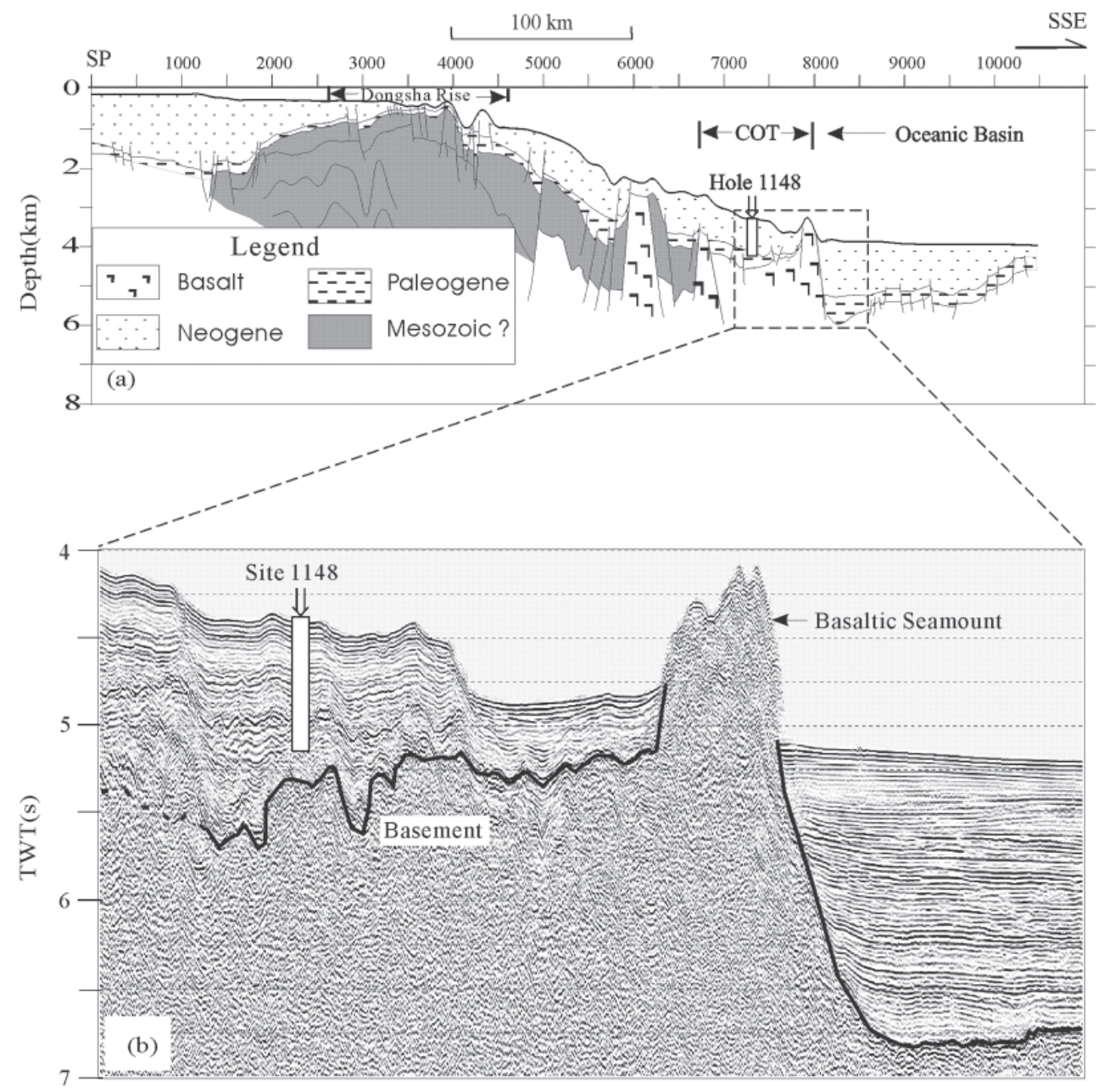

Fig. 3. Interpreted seismic profile L1 (a) through ODP site 1148 shows a magmatism-disturbed continental-oceanic transition zone (COT). A migrated seismic profile (b) illustrates a shallow basaltic basement underneath Hole 1148 and the adjacent volcano.

Crown, scarps, tips, steep slide surfaces and faults (the nomenclatures follow Varnes 1978) can be easily identified from the seismic profile. Due to chaotic reflection, the bottom slip surface can't be discerned clearly on the upper and middle slope. However, the slump-disturbed sediments are estimated to have an averaged thickness of $600 \mathrm{~m}$ for the main body (providing the interval two way time be $0.6 \sim 1 \mathrm{~s}$ with an assumed interval velocity of $1.8 \mathrm{~km} \mathrm{~s}^{-1}$ ). 
On the lower slope where the morphology becomes relatively smooth and the slide surface dips in low angle, the slump body appears as a single low dune, possibly, of debris-flow accumulation. Although the distribution of the slump zone parallel to the slope is not clearly defined due to very low coverage of the geophysical survey, it can be estimated to be $150 \sim 200 \mathrm{~km}$ according to the geometry of bathymetric contours (Fig. 1). Therefore, the whole slump zone is about $10000 \sim 20000 \mathrm{~km}^{2}$.

As most deformations relating to the slumping is limited upon $\mathrm{T}_{2}$ reflector (mid-Miocene), the slump might happen instantaneously or episodically from that time to the Recent. The presence of a seafloor scar may imply much younger sliding activity.

Over the mid-slope, there are possible BSRs ca. $0.2 \sim 0.3 \mathrm{~s}$ beneath the seafloor (Fig. 2). Between the seabed and the possible BSRs is a zone of weak reflection, i.e., a white zone. Under the BSRs, the highly deformed reflectors appear stronger. The seismic profile also shows a mud diapirism mound sitting within the slump complex, but somewhat out of the survey line (Fig. 2).

\subsection{The Area of the Dongsha Islands (Area II)}

A multi-channel seismic line L1 through ODP site 1148 shows a major tectonic variation from the continental slope southward to the oceanic basin. The upper slope is smooth while the middle and lower slope is very rough. The slope width is ca. $350 \mathrm{~km}$. On the upper slope, thick Meso-Cenozoic deposits are found in the depression. The basement is not imaged. A submarine plateau composed of the Mesozoic strata, lying on the middle slope, is capped by thin (200 - $1000 \mathrm{~m}$ ) Cenozoic deposits. The lower slope spanned by the continental-oceanic transition zone (COT), is highly disturbed by magmatism. Young volcanoes have pierced the MesoCenozoic sediment intervals to the sea floor or into shallow depths underneath the sea floor. The ages of these volcanoes are correlated to be of the post-spreading phase, most probably Quaternary period (Yan et al. 2006). It is commonly seen that the reflections sequences were deformed in parallel along with dense, sub-vertical fissures from the basement through to the seabed over the magmatism-disturbed portion. A minor slump occurred locally, e.g., at the Site 1148 (Wang et al. 2000). The direct cause of the parallel deformation and slump may be differential uplift and subsidence. The ODP Site 1148 is on the lower slope with a basaltic basement and young volcanoes (Fig. 3). A high-above-sea-floor volcanic seamount on the slope base acts as a landmark separating the oceanic basin where the deposits appear undisturbed from the highly disturbed slope.

Additionally, the seismic profile of Sonne 95 - 10 (Lüdmann et al. 2005) also shows a high seamount (1500 m above the seafloor) and is most probably basaltic, some $10 \mathrm{~km}$ north of site 1144. The proposed BSR at ca. $3.5 \mathrm{~s}$ TWT (Song et al. 2001; Wu et al. 2003b) are actually reflections of the top magmatic basement under the site 1144 (Lüdmann et al. 2005). Deposits there are very thin, in the hundreds meters (Wang et al. 2000). Basically, no BSR has been found from L1 and neighboring survey lines.

\subsection{The Western Area of the Dongsha Islands (Area III)}

Facing the estuary of the Pearl River, the western Dongsha area has the smoothest slope 
along with the deepest Cenozoic extensional depression (Fig. 4). In the depression center, the deposits thicknesses were maximized to $11 \mathrm{~km}$ (Pang et al. 2004; Huang et al. 2005b). The shelf break is not clearly defined. Providing the $150 \mathrm{~m}$ bathymetry as the shelf break, the slope width would be ca. $150 \mathrm{~km}$ at this locale. Locally rugged topography appears on the mid slope. Figure 5 shows a portion of the MCS seismic profile L1500 running through this area (Fig. 1) and a portion of sub-bottom profile SB2, which almost coincides with L1500. The seismic profiles revealed prominent mound-like, sigmoid, cross-bedding reflections. In Fig. 5, medium to minor (with 30 - $200 \mathrm{~m}$ fall), recent and ancient slump bodies can be found, but the internal deformations are very weak. The slump is evidenced by step-wise throwing of the sub-horizontal reflectors in the sub-bottom profile (see the inset of Fig. 5b). Some slump is rotational (Fig. 5b).

Figure 6 shows a portion of single-channel seismic profile ZD84 through the central Pearl River Mouth Basin (see location in Fig. 1). The profile was collected a decade ago and proprietarily own by the GMGS. With this profile, Feng et al. (1996) has identified the mound like collapsed sedimentary structures. They might be formed by slump and debris flow. It can also be found that possible BSRs exist $200 \sim 300 \mathrm{~m}$ beneath the middle slope seafloor (Fig. 6).

\section{DISCUSSION}

As noted above, it can be concluded that the geology of the Dongsha Region varies greatly. The eastern Dongsha area is predominated by a huge recent slide-slump zone (SD-1 and SD-2 in Fig. 1). Lüdmann et al. (2001) has also found the occurrence of recent slumping on the midslope. On the lower slope in the south ( $>3000$ m water depth), Damuth (1980) have found a large field $\left(20000 \sim 25000 \mathrm{~km}^{2}\right)$, extending southward to the wall of the Manila Trench, a result of migrated waves led by turbidity currents, not contour currents. It coincides and partially overlaps with the slide/slump body we found. Damuth (1980) has also found another large (ca. $4000 \sim 5000 \mathrm{~km}^{2}$ ) slump-debris complex (SD-2 in Fig. 1) on a continental rise (between $3300-3750 \mathrm{~m} ; 19^{\circ}-20^{\circ} \mathrm{N}, 19^{\circ}-20^{\circ}$ ) in the south where the seafloor begins to bend

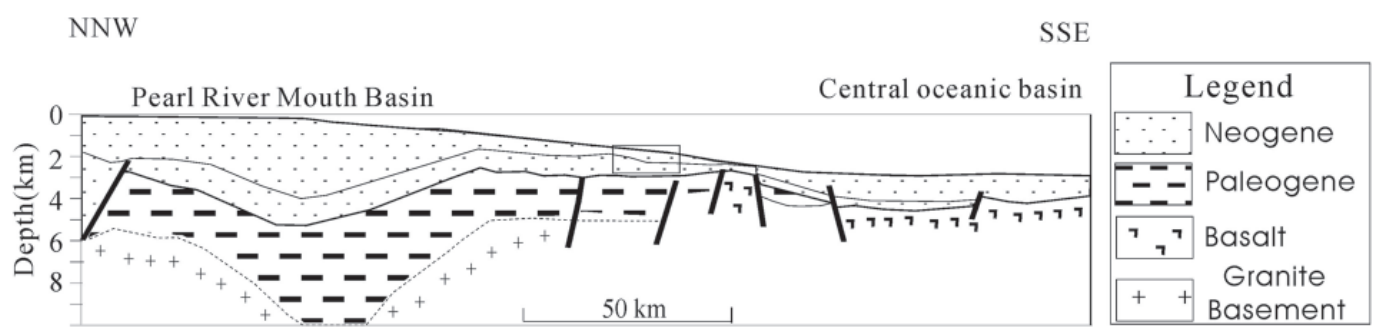

Fig. 4. A conceptual interpretation of seismic lines crossing the deepest depression of the Mouth of the Pearl River Basin. The inset box is the projected location of Fig. 5a. 


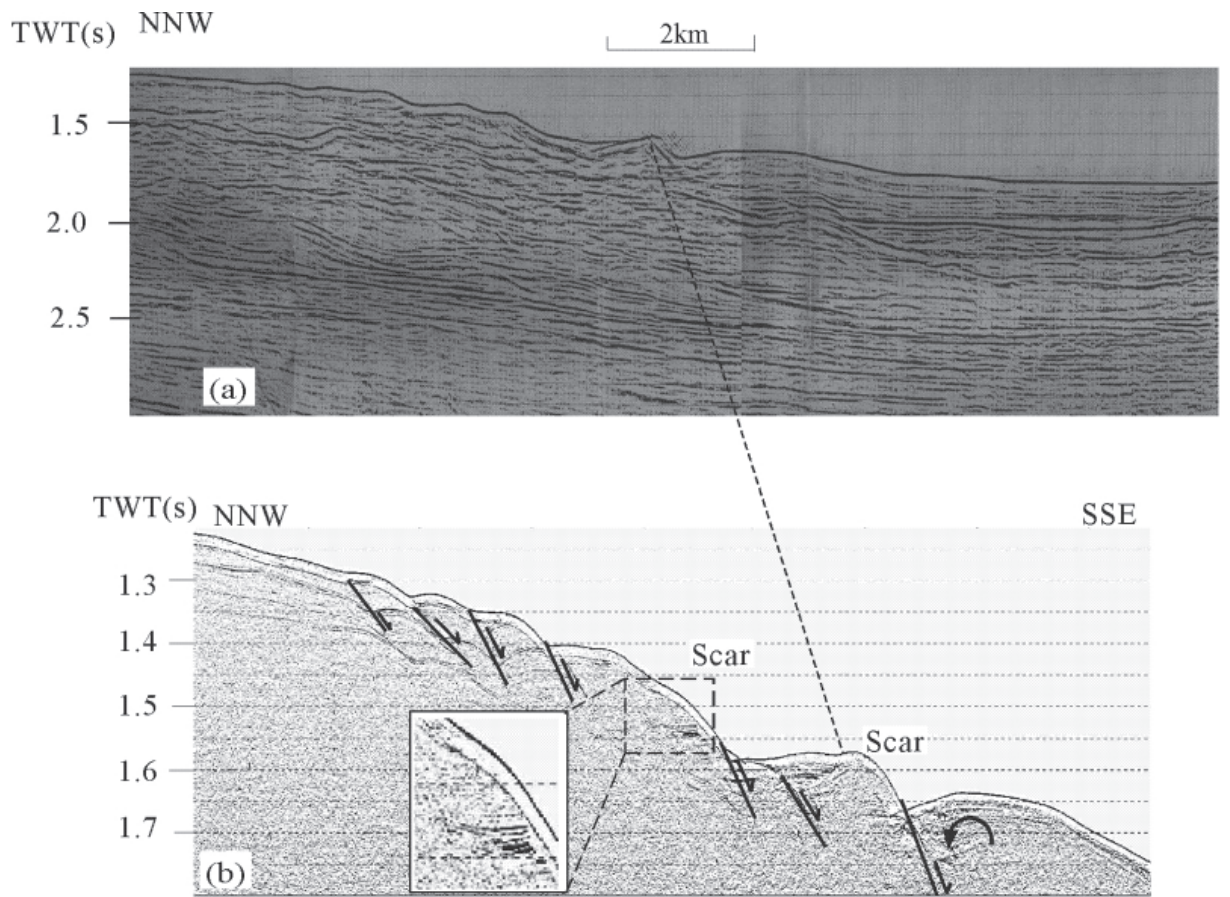

Fig. 5. Portions of the MCS profile L1500 (a) and sub-bottom profile SB2 (b) at mid slope. Note, the MCS profile (a) and sub-bottom profile (b) does not coincide completely in location, but their location nuance is too small to be shown on map (Fig. 1).

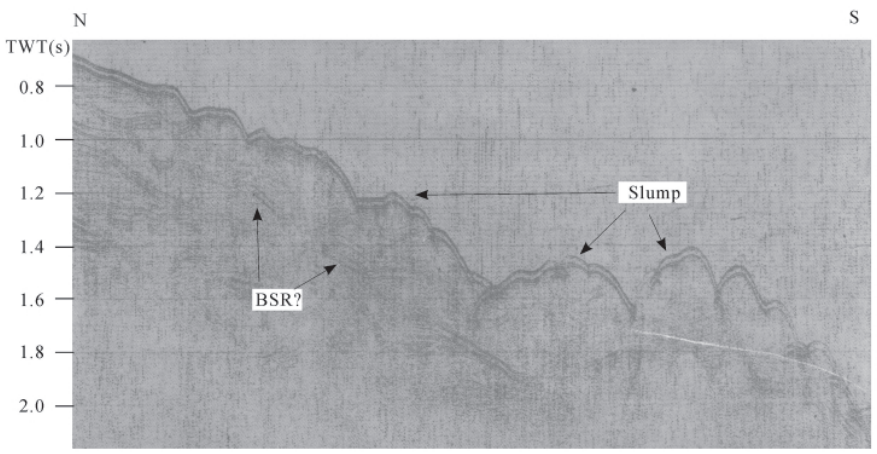

Fig. 6. A portion of single channel seismic profile which shows a slump and possible BSR over the mid-slope (refer to Feng et al. 1996). The location is seen as ZD84 in Fig. 1. 
down into the Manila Trench. Therefore, the east Dongsha area hosts the biggest slide-slump complex with an area total of $25000 \sim 30000 \mathrm{~km}^{2}$ (including the slope portion and its extension in the west wall of the Manila Trench).

The factors leading to the slope failure can be followed both externally and internally. The external factors include geo-stress variation, due to wave loading, tectonic extension, earthquakes or magmatism, while the internal factor includes low slope strength, due to poor consolidation, high pore pressure, or gas seep, etc. It is true that the collision of Luzon Arc with Taiwan Island and the South China Sea has produced notorious earthquakes concentrated onshore and offshore the island of Taiwan. However, extensive seismic profiles have only revealed small slump structures on the proximal SW slope of offshore Taiwan where large accretionary wedges have actively developed (Liu et al. 2004). Earthquakes may not be a chief factor for the slide/slump in the distal Dongsha slope. Wave and sea-level fluctuations can exert some effect, but not to great depth. Regional tectonic extension has almost stopped since the cessation of seafloor spreading of the South China Sea. Young magmatism is not seen nearby. Therefore, we believe the accumulated gravity loading and the internal factor, such as increased pore pressure have jointly affected the slope failure. Analysis of the dredged deposits from the lower slope shows a terrigenous provenance (Damuth 1980). Thick deposits transported through the wide northeast shelf down to the steep slope breeds high instability. The thick terrigenous deposits might provide abundant organic matter, and the active sliding and slumping may accommodate passages for the upward migration of gas, if present, and is therefore favorable for the formation of gas hydrate.

Recently, Huang et al. (2005a), and Chen et al. (2005) have found ample seep carbonates and methane oxidizing archaer and sulfate reducing bacteria fossils near the seismic line L6 (Fig. 1) on the slope which further proves the area as hopeful for prospect of gas hydrate. A low relief structure (JMR in Fig. 1) is even named as Jiulong Methane Reef due to the presumable high likelihood of gas hydrate occurrence (Huang et al. 2005a). Follow the name, we name the giant slide/slump complex here (SD-1 in Fig. 1) as Jiulong Slump.

The middle and lower slope of the central Dongsha area is covered with thin Cenozoic, mainly Neogene deposits (Lüdmann et al. 2001, 2005). Lüdmann et al. (2005) concluded that the deposits over Site 1144 are mainly drift sediments derived by upward flow. We conjecture that the deposits over the Sites 1147, 1148, which lie down-slope are also drift deposits. However, vigorous younger magmatism has intruded into or erupted onto the lower slope, resulting in a heated environment. The heat flow is generally high $\left(70 \sim 90 \mathrm{~mW} \mathrm{~m}^{-2}\right.$ or even higher) (He et al. 2001). Temperature gradient values at most sites of the ODP 184 (Wang et al. 1999), except Site 1144, are very high (Fig. 7). At Site 1148, the temperature gradient is $83^{\circ} \mathrm{C} \mathrm{km}^{-1}$. With very short portions of seismic profiles, Song et al. (2001) proposed that BSRs existed ca. $0.9 \mathrm{~s}$ and $0.6 \mathrm{~s}$ beneath the seafloor at Sites 1148 and 1144, respectively. The proposed BSRs would represent ca. $500 \mathrm{~m}$ and $700 \mathrm{~m}$ stable thickness for gas hydrate. At Site 1148, the high temperature gradient $83^{\circ} \mathrm{C} \mathrm{km}^{-1}$ would imply at least $40^{\circ} \mathrm{C}$ at the depth, therefore resulting too high temperature for occurrence of gas hydrate. The very low headspace methane content $(1 \sim 100$ ppmv) (Wang et al. 2000) through the logged section further rules out the possibility of gas hydrate, thus, negating the possibility of BSR at that one location. A tricky phenomenon appears for Site 1144 , where the temperature gradient is only $24^{\circ} \mathrm{C} \mathrm{km}^{-1}$. That value implies that 
the proposed BSR at that particular site fall within the stable range for gas hydrate, and further, the headspace methane content exceeds $10^{4} \mathrm{ppmv}$ and approximates to $10^{5} \mathrm{ppmv}$ from 10 mbsf downward (Wang et al. 2000). However, upon viewing the more complete seismic profile through Site 1144 (Lüdmann et al. 2005), the BSR proposed by Song et al. (2001), is unequivocally correlated as basement reflection. This tricky phenomenon deserves more study as the sedimentary and geophysical features show a very unfavorable geological environment for occurrence of gas hydrate over this area.

The western Dongsha area kept a subsiding tendency since the early continental rifting. The deepest depression accommodates a large space for the terrigenous deposits from the Pearl River, ancient and modern, in a long stable tectonic setting. Medium to minor slumps are readily found across the middle slope, but no obvious external dynamic processes act as the trigger mechanism due to its even larger distance from regionally tectonic activities (magmatism, plate convergence et al.). Therefore, unconsolidation due to fast sedimentation, and high ventilation of gas or liquid may again be responsible for the slope instability. Although BSR is not found widespread here as in the offshore SW Taiwan (Deng et al. 2006; Liu et al. 2006), this area represents excellent prospects for the discovery of GH. This area may represent an GH area of diffusive type, that features ample vents, and weak or non BSR (Chen et al. 2006).

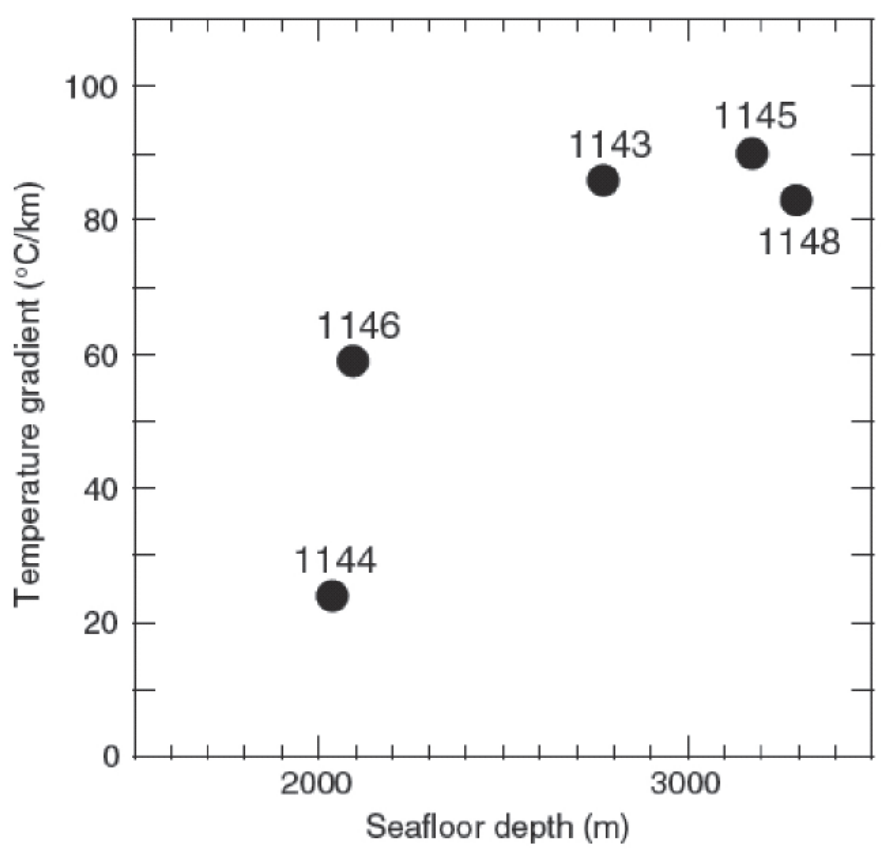

Fig. 7. Temperature gradients measured from the ODP 184 Leg (Wang et al. 1999). 


\section{CONCLUSION}

The geology varies greatly over the different sectors of the Dongsha Slope and therefore constrains the accumulation of gas hydrates.

In the east Dongsha slope area, Jiulong Slump comprises large mass wasting (landslide, slump, debris flow, etc.) bodies developed from the shelf break to the continental rise, with an area totaling ca. $20000 \sim 30000 \mathrm{~km}^{2}$ along with the nearby continental rise slump complex. It may be the largest in the South China Sea and even one of the largest submarine slide/slump complexes in the global oceans. Medium-weak BSR may exist on the mid-slope and is the most hopeful prospect for the occurrence of gas hydrate.

The central Dongsha slope area, with very thin Cenozoic sediments, was tectonically highly disturbed by the latest Cenozoic uplifting and magmatism events. The sedimentological factors along with high heatflow values and geothermal gradients are unfavorable for occurrence of gas hydrate.

The west Dongsha slope area is occupied by the deepest depression that hosts $11 \mathrm{~km}$ thick Cenozoic deposits and very bright prospects for petroleum. The occurrences of moderate to minor slumps upon the thick deposits on the mid slope may predict favorable geologic conditions, e.g., active migration of gas, high porosity, etc., for gas hydrate.

Acknowledgements This study is supported by Chinese Academy of Sciences Knowledge Innovation Program (No. KZCX2-YW-203-01, KZCX3-SW-224), National Natural Science Foundation of China (No. 40376012). The Shiyan II and Tanbao crews deserve acknowledgement in the collection of geophysical data. Louis S. Teng, Dennis Brown, C. Y. Huang, and T. F. Yang must be thanked for their corrections and suggestions in revision of the manuscript. The bathymetry charts were generated using GMT software (Wessel and Smith 1995).

\section{REFERENCES}

Chen, D. F., Y. Y. Huang, X. L. Yuan, and L. M. Cathles, 2005: Seep carbonates and preserved methane oxidizing archaea and sulfate reducing bacteria fossils suggest recent gas venting on the seafloor in the Northeastern South China Sea. Mar. Petrol. Geol., 22, 613-621.

Chen, D., X. Li, and B. Xia, 2004: Distribution of gas hydrate stable zones and resource prediction in the Qiongdongnan Basin of the South China Sea. Chin. J. Geophys., 47, 483-489. (in Chinese)

Chen, D. F., Z. Su, and L. M. Cathles, 2006: Types of gas hydrates in marine environments and their thermodynamic characteristics. Terr. Atmos. Ocean. Sci., 17, 723-737.

Cheng, W. B., 2004: Crustal structure of the high magnetic anomaly belt, western Taiwan, and its implications for continental margin deformation. Mar. Geophys. Res., 25, 79-93.

Chi, W. C., D. L. Reed, C. S. Liu, and N. Lundberg, 1998: Distribution of the bottom simulating reflector in the offshore Taiwan collision zone. Terr. Atmos. Ocean. Sci., 9, 779-792.

Damuth, J. E., 1980: Quaternary sedimentation processes in the South China Basin as re- 
vealed by echo-character mapping and piston-core studies. In: Hayes, D. E. (Ed.), The Tectonic and Geologic Evolution of Southeast Asian Seas and Islands, Part 1. American Geophysical Union Geophysical Monograph, 23, 105-125.

Deng, H., P. Yan, and H. Liu, 2005: An analysis on BSR in southwest Taiwan area. J. Trop. Oceanogr., 24, 79-85. (in Chinese)

Feng, Z. Q., W. K. Feng, W. J. Xue, Z. H. Liu, J. R. Chen, and W. F. Li, 1996: Evaluation of marine geological hazards and engineering geological conditions in the northern South China Sea. Hehai University Publishing House, Nanjing, China. (in Chinese).

Hao, H. J., H. M. Lin, M. X. Yang, H. Y. Xue, and J. Chen, 2001: The Mesozoic in Chaoshan Depression: A new domain of petroleum exploration. China Offshore Oil Gas Geol., 15, 157-163. (in Chinese)

He, L. J., K. L. Wang, L. P. Xiong, and J. Y. Wang, 2001: Heat flow and thermal history of the South China Sea. Phys. Earth Planet. In., 126, 211-220.

Huang, Y., E. Suess, and N. Y. Wu, 2005a: Geological background and proof of the occurrence of gas hydrate in the northeastern Dongsha Waters. Abstract presented at the Symposium on Gas Hydrate across Taiwan Strait, Chenggong University, China. (in Chinese)

Huang, C., D. Zhou, C. Chen, Z. Sun, and H. Hao, 2005b: Deep crustal structure of Baiyun Depression revealed by deep reflection seismic profile. Bull. Sci., 50, 1024-1031. (in Chinese)

Liu, C. S., B. Deffontaines, C. Y. Lu, and S. Lallemand, 2004: Deformation patterns of an accretionary wedge in the transition zone from subduction to collision offshore southwestern Taiwan. Mar. Geophys. Res., 25, 123-137.

Liu, C. S., P. Schnürle, Y. Wang, S. H. Chung, S. C. Chen, and T. H. Hsiuan, 2006: Distribution and characters of gas hydrate offshore of southwestern Taiwan. Terr. Atmos. Ocean. Sci., 17, 615-644.

Lüdmann, T., and H. K. Wong, 1999: Neotectonic regime on the passive continental margin of the northern South China Sea. Tectonophysics, 311, 113-138.

Lüdmann, T., H. K. Wong, and P. Wang, 2001: Plio-Quaternary sedimentation processes and neotectonics of the northern continental margin of the South China Sea. Mar. Geol., 172, 331-358.

Lüdmann, T., H. K. Wong, and K. Berglar, 2005: Upward flow of North Pacific Deep Water in the northern South China Sea as deduced from the occurrence of drift sediments. Geophys. Res. Lett., 32, L05614, doi:10.1029/2004GL021967.

McDonnell, S., M. Max, N. Cherkis, and M. F. Czarnecki, 2000: Tectono-sedimentary controls on the likelihood of gas hydrate occurrence near Taiwan. Mar. Petrol. Geol., 17, 929-935.

Pang, X., S. Yang, M. Zhu, and J. Li, 2004: Deep-water fan systems and petroleum resources on the northern slope of the South China Sea. Acta Geol. Sinica, 78, 626-663.

Schnürle, P., T. H. Hsiuan, and C. S. Liu, 1999: Constraints on free gas and gas hydrate bearing sediments from multi-channel seismic data, offshore Southwestern Taiwan. Petrol. Geol. Taiwan, 33, 21-42. 
Shyu, C. T., S. K. Hsu, and C. S. Liu, 1998: Heat flows off southwest Taiwan: measurements over mud diapirs and estimated from bottom simulating reflectors. Terr. Atmos. Ocean. Sci., 9, 795-812.

Sibuet, J. C., S. K. Hsu, X. Le Pichon, J. P. Le Formal, R. Reed, G. Moore, and C. S. Liu, 2002: East Asia plate tectonics since 15 Ma: constraints from the Taiwan region. Tectonophysics, 344, 103-134.

Song, H., J. Geng, H. K. Wang, W. Zhang, Y. Fang, T. Hao, and W. Jiang, 2001: A preliminary study of gas hydrate in Dongsha region north of South China Sea. Chin. J. Geophys., 44, 687-695. (in Chinese)

Taylor, B. and D. E. Hayes, 1983: Origin and history of the South China Basin. In: Hayes D. E. (Ed.), The Tectonic and Geologic Evolution of Southeast Asian Seas and Islands, Part 2. Geophys. Monogr. Ser., 27. AGU, Washington, DC, 23-56.

Varnes, D. J., 1978: Slope movement types and processes. In: Schulster, R. L., and R. J. Krizek (Eds.), Landslides, Analysis and Control, Special Report 176. National Academy of Sciences, Washington, DC, 11-33.

Wang, P., W. L. Prell, P. Blum, J. Baldauf, and P. Blum, 1999: Ocean Drilling Program, Leg 184 Preliminary Report: South China Sea, College Station, Taxes.

Wang, P., W. L. Prell, and P. Blum, 2000: Seismic reflection stratigraphy of Leg 184, South China Sea. Proceedings of the Ocean Drilling Program, Initial Reports, Volume 184 (184IR-102).

Wessel, P. and W. H. F. Smith, 1995. New version of the generic mapping tools (GMT) version 3.0 released, Trans. AGU, Eos, 76, 329.

Wu, B., G. Zhang, Y. Zhu, Z. Lu, and B. Chen, 2003a: Progress of gas hydrate investigation in China offshore. Earth Sci. Frontiers, 10, 177-189. (in Chinese)

Wu, S., Z. Liu, W. Wang, J. Guo, T. Lüdmann, and H. K. Wong, 2003b: Late Cenozoic tectonic deformation in the Dongsha islands and adjacent sea area. Chin. J. Oceanol. Limnol., 21, 377-388. (in Chinese)

Wu, S., G. Zhang, Y. Huang, J. Liang, and H. K. Wong, 2005: Gas hydrate occurrence on the continental slope of the northern South China Sea. Mar. Petrol. Geol., 22, 403-412.

Yao, B, 1998: Preliminary exploration of gas hydrate in the northern margin of the South China Sea. Mar. Geol. Quat. Geol., 18, 11-18. (in Chinese)

Yan, P., H. Deng, H. Liu, Z. Zhang, and Y. Jiang, 2006: The temporal and spatial distribution of volcanism in the South China Sea region. J. Asian Earth Sci., 27, 647-659.

Yan, P., D. Zhou, and Z. Liu, 2001. A crustal structure profile across the northern continental margin of the South China Sea. Tectonophysics, 338, 1-21.

Yan, P., H. Deng, and H. Liu, 2006: The geological structure and prospect of gas hydrate over the Dongsha Slope, South China Sea. Terr. Atmos. Ocean. Sci., 17, 645-658. 